UNDERGRADUATE RESEARCH IN NATURAL AND CLINICAL SCIENCE AND TECHNOLOGY (URNCST) JOURNAL Read more URNCST Journal articles and submit your own today at: https://www.urncst.com

\title{
Resurrecting the Dead: Mitigating Efflux-Pump Inhibitor Toxicity Using a Liposomal Delivery System to Recover Efficacy of Antimicrobial Drugs
}

\author{
Prachi Ray, BSc Student [1]*, Kha Nguyen, BSc Student [2], Truong Nguyen, \\ BSc Student [2], Sukriti Sachdev, BSc Student [3]
}

[1] Department of Pharmacology \& Toxicology, University of Toronto, Toronto, Ontario, Canada M5S 1A1

[2] Department of Biochemistry, University of Toronto, Toronto, Ontario, Canada M5S 1A1

[3] Department of Human Biology, University of Toronto, Toronto, Ontario, Canada M5S 1A1

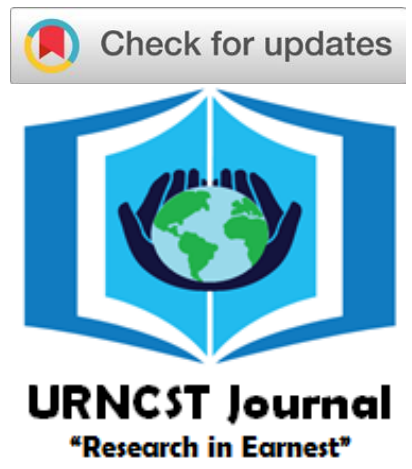

*Corresponding Author: prachi.ray@mail.utoronto.ca

\begin{abstract}
Introduction: Antimicrobial resistance (AMR) has become concerningly prevalent on a global scale as many infectious agents have evolved to evade antimicrobials effects, making it difficult to treat infectious diseases. Pseudomonas aeruginosa is a multiresistant bacteria that requires urgent attention as it is detrimental in lung infections. Activity of membraneembedded efflux pumps, such as the MexAB-OprM pump, is a principal mechanism by which bacterial species become resistant to antimicrobials. Efflux pump inhibitors (EPIs) have recently emerged as a strategy to prevent the expulsion of administered antimicrobials, thereby resensitizing resistant bacteria to antibiotics. Phenylalanine-arginine $\beta$-naphthylamide $(\mathrm{PA} \beta \mathrm{N})$ is an EPI that inhibits a number of different pumps, including the MexAB-OprM efflux system. Despite EPIs providing a partial solution to AMR, they have been shown to be toxic to humans, which has impeded their entry into clinical application. We propose that by inserting the PA $\beta \mathrm{N}$ into a liposomal delivery system, the cytotoxic effects against human cells will be lowered without decreasing the EPI's inhibitory activity.

Methods: Resistant P. aeruginosa strains will be administered with liposomes jointly encased with PA $\beta \mathrm{N}$ and ampicillin to ensure both are delivered to the same cell, while testing for changes in antimicrobial efflux activity and bacterial growth, indicative of restored antimicrobial effectiveness. Efflux activity and inhibited growth will be measured using an ethidium bromide efflux assay and a minimum inhibitory concentration assay, respectively. Human pulmonary epithelial cells will be exposed to liposomal-encased PA $\beta \mathrm{N}$ to study changes to EPI cytotoxicity, with cell viability being measured using a Cell Titer Blue assay.

Results: Liposomal EPI are expected to maintain inhibitory activity and resistant bacteria would become re-susceptible to antibiotics when treated with the liposomal EPI.

Discussion: By analyzing efflux rate to measure the liposomal EPI's activity, its activity level should be comparable to free EPI. The resensitization assay would show that the bacteria are susceptible to antibiotics again.

Conclusion: If effective, EPIs may become a potential therapeutic to combat AMR by reviving the use of antimicrobials that have become ineffective. Restoring the activity of already approved antibiotics through potential co-administration with liposome-encapsulated EPIs will be a cost-effective approach to combat AMR.
\end{abstract}

Keywords: antimicrobial resistance; efflux-pump inhibitors; liposomes; drug delivery; cytotoxicity; Pseudomonas aeruginosa; minimum inhibitory concentration

\section{Introduction}

Infectious agents, namely bacteria, viruses, and fungi are capable of invading cells and causing damage to various organisms, including humans [1]. This damage can be reduced through antimicrobials, however misuse and overuse has led to the emergence of antimicrobial resistance (AMR) [1]. According to the World Health Organization, one of the top 3 critical priority pathogens that requires the development of new antibiotics is
Pseudomonas aeruginosa, which is known to cause fatal lung infections in patients with cystic fibrosis [2-4].

One mechanism for AMR in P. aeruginosa is through the overexpression of multidrug efflux pumps, which remove cytotoxic substances from infectious cells, making it difficult for antimicrobials to exert their effects $[5,6]$. $P$. aeruginosa intrinsically expresses the MexAB-OprM pump, an efflux pump system part of the Resistancenodulation-cell division superfamily $[5,6]$. Consequently, 
MexAB-OprM plays an important role in the emergence of AMR in $P$. aeruginosa.

Given that overexpression of efflux pumps is a prevalent mechanism by which bacteria develop AMR, efflux pump inhibitors (EPIs) have recently emerged as compounds that function as a competitive inhibitor of these pumps [7,8]. EPIs are designed to be co-administered alongside antibiotics, thereby preventing or decreasing the amount of antimicrobial drugs pumped out of the bacterial cell, which increases the efficacy of these drugs $[9,10]$.

Phenylalanine-arginine $\beta$-naphthylamide $(\mathrm{PA} \beta \mathrm{N})$ is an EPI that inhibits a number of different bacterial efflux pumps, including the MexAB-OprM efflux system [11]. Despite the benefits of EPIs, they have been shown to be toxic to host cells, as evident through a number of in vivo studies, however the explanation for why EPIs can be toxic to human cells is still unknown [12]. This toxicity is the key barrier preventing the progression of EPIs to a clinical setting $[13,14]$.

Improving drug delivery systems has recently surfaced as a unique approach to restore the activity of promising therapeutic compounds that present complications in vivo. Specifically, liposomal drug delivery is a promising strategy, as many liposome encapsulated drugs are currently undergoing clinical trials [15-17]. Liposomes act as an effective vehicle to bring active compounds to their target site, therefore increasing drug bioavailability $[18,19]$. This allows liposomes to decrease the dosage required to achieve a therapeutic effect and therefore improve the safety profile of these drugs.
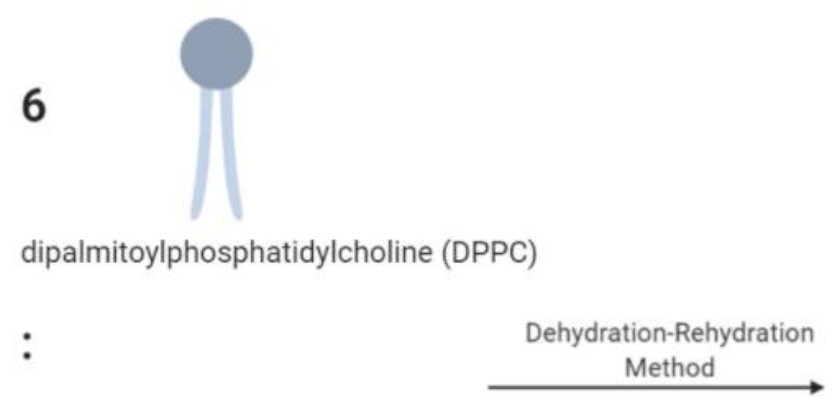

:

1

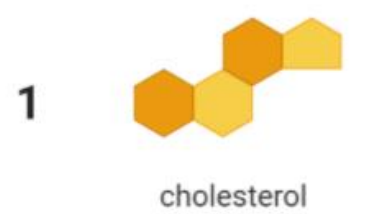

cholesterol

dipalmitoylphosphatidylcholine (DPPC)
Research Hypothesis

If $\mathrm{PA} \beta \mathrm{N}$ is encapsulated within dipalmitoylphosphatidylcholine (DPPC)-cholesterol liposomes and co-administered with ampicillin, then the antibiotic will be able to inhibit the growth of resistant $P$. aeruginosa strains without cytotoxic effects from the EPI to human pulmonary epithelial cell viability.

\section{$\underline{\text { Rationale }}$}

Since EPIs are promising therapeutic compounds that may help to overcome bacterial resistance to antibiotics, it is worthwhile to explore ways to improve their delivery. Using a liposomal delivery system is a promising technique to reduce drug toxicity, given its recent success in improving the bioavailability of other drugs and decreasing the levels required to achieve a pharmacological effect.

\section{Methods}

\section{Liposome Encapsulation}

Since neutrally-charged liposomes are known to have higher bioavailability in plasma [20], neutral liposomes will be created by mixing dipalmitoylphosphatidylcholine and cholesterol in a 6:1 ratio using the dehydration-rehydration method as follows: the DPPC-cholesterol mixture will be dissolved in a solution of chloroform and methanol at a 2:1 ratio; after evaporating the organic solvent using a rotary evaporator (Rotavapor), a liposome layer will form. PA $\mathrm{N}$ will be inserted into the liposome through sonication (Figure 1) [21]. Using dynamic light scattering, the sizes of the liposomes can be analyzed, which can also verify if they were successfully generated. Liquid chromatography-mass spectrometry may then be used to verify that the drugs are encapsulated in the liposomes.
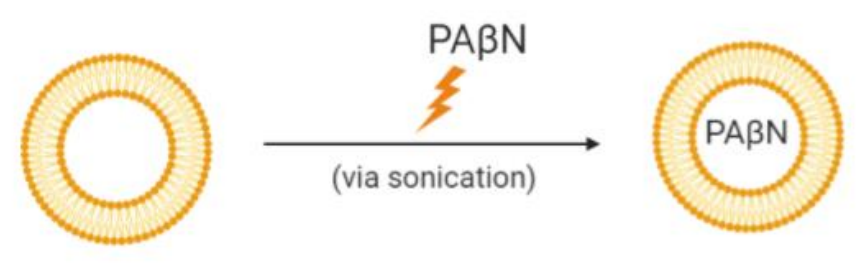

Figure 1. Liposome formation using a DPPC-cholesterol mixture, followed by the insertion of PA $\beta \mathrm{N}$ within the liposome. Figure created with BioRender.com. 
$\underline{\text { Minimum Inhibitory Concentration (MIC) Assay }}$

$P$. aeruginosa strain PA-Y7 is a highly resistant strain through the expression of MexAB-OprM [22]. Three cell cultures will be used: wildtype $P$. aeruginosa, MexABOprM overexpressing, and MexAB-OprM knockout (KO) cells. Cultures will be incubated in a 96-well plate with increasing concentrations $(0,125,250,500$, and 1000 $\mu \mathrm{g} / \mathrm{mL}$ ) of ampicillin, produced by serial dilution with 0 $\mu \mathrm{g} / \mathrm{mL}$ as the control. After a 24-hour incubation period at $37^{\circ} \mathrm{C}$, each plate will be tested for inhibited growth by assessing optical density (OD) at $600 \mathrm{~nm}$ (OD600). On the plate, the antibiotic treatment will be done twice to account for within-plate variability, while the assay will be conducted as triplicates. Lower concentrations of ampicillin will still allow growth of $P$. aeruginosa, demonstrating the efflux abilities [23]. MexAB-OprM overexpressing strains will be expected to have a higher MIC than the wildtype strain (Figure 2), whereas knockouts will be expected to be more susceptible to ampicillin.

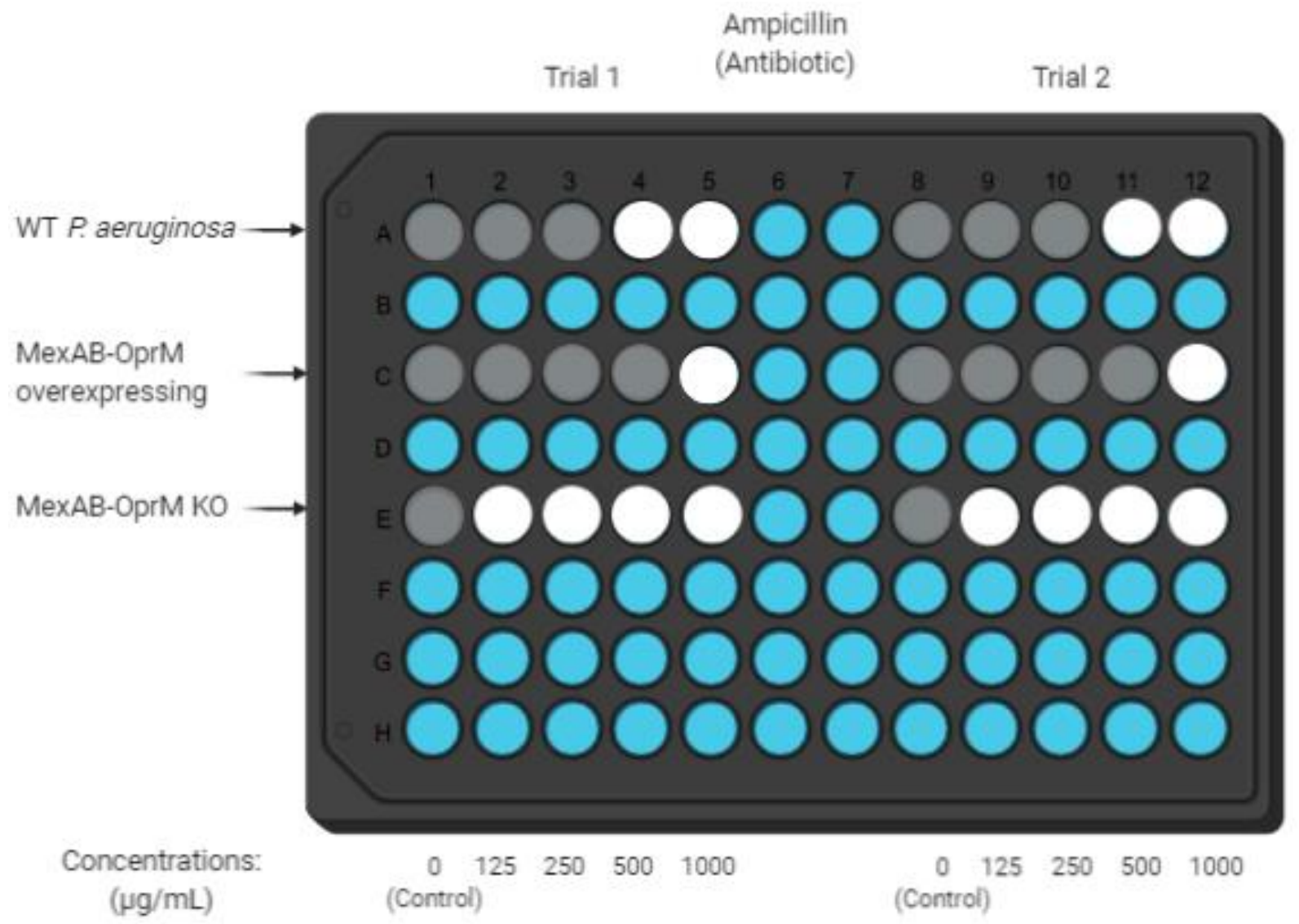

Figure 2. Expected MIC assay to assess the role of MexAB-OprM for the evolution of resistance in P. aeruginosa. Grey $=$ bacterial growth; white $=$ inhibited growth; blue $=$ empty well. Figure created with BioRender.com .

\section{Determining Liposomal EPI Cytotoxicity}

Using a human pulmonary epithelial cell line (A549), a Cell Titer Blue assay will be used to determine cell viability [21]. Cells will be seeded into a 24 well plate in cell culture media with free or liposomal EPI at different concentrations, and cell culture media alone as the control.
Cells are then left to incubate for 24 hours, before replacing the existing media with fresh media containing resazurin, a fluorogenic dye. Cell culture media with resazurin will be used as a baseline measure. Living cells can convert resazurin to fluorescent resorufin. Following this, fluorescence is measured to determine cell viability (Figure 3 ). 


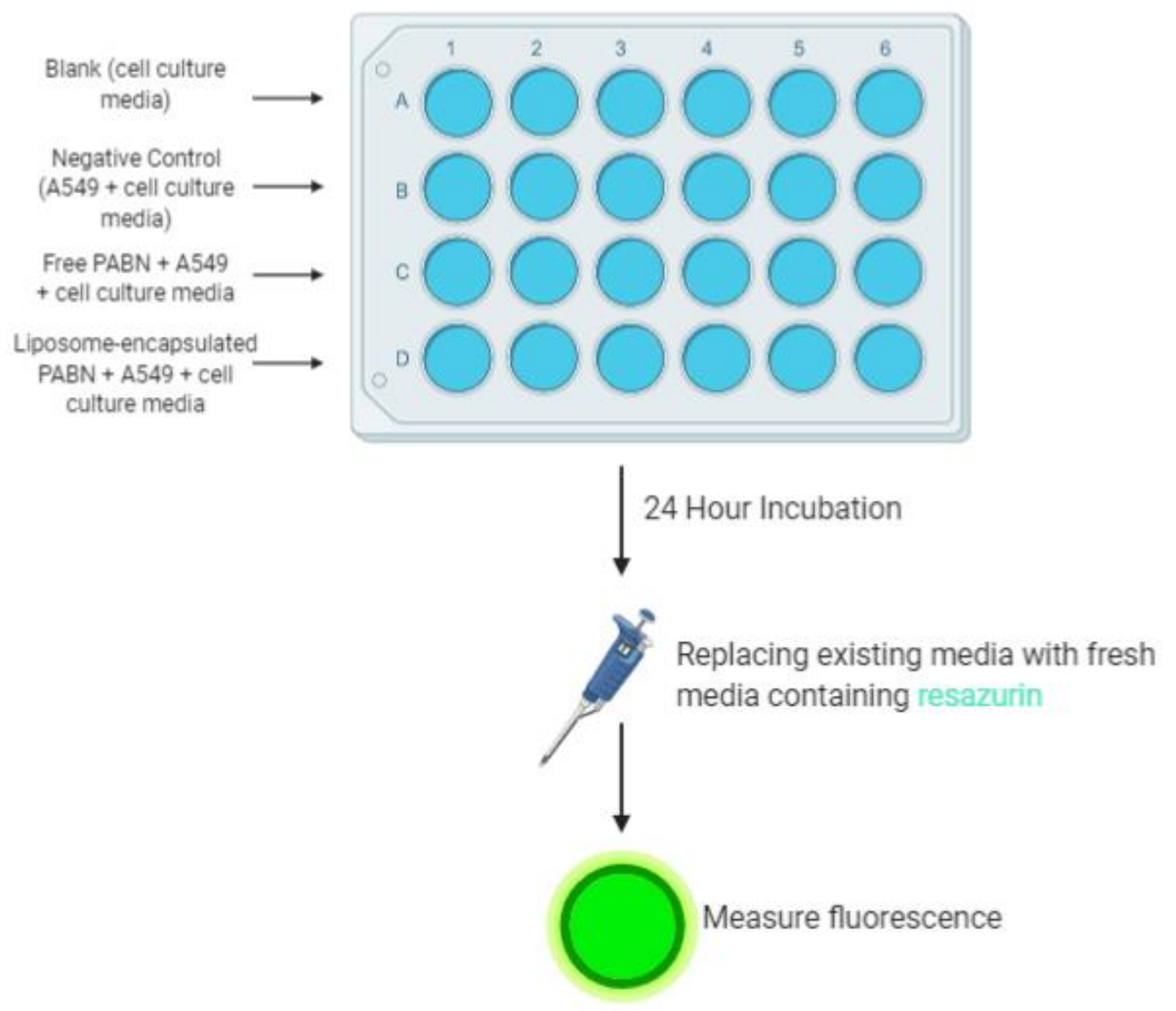

Figure 3. Cell Titer Blue assay to evaluate the liposomal PAßN's cytotoxic effect on human cells. A549 is a human pulmonary epithelial cell line and cell viability is determined using fluorescence, which will be measured using a fluorimeter [24]. Figure created with BioRender.com.

\section{Measuring Inhibition of Pump's Efflux Activity}

Using $P$. aeruginosa expressing MexAB-OprM grown in media, a protonophore, such as carbonyl cyanide $\mathrm{m}$ chlorophenylhydrazone (CCCP), is added to temporarily stop the pumps [24,25]. Following this, one of three treatment groups will be administered: control (only ethidium bromide (EtBr)), free EPI with EtBr or liposomal EPI with EtBr. The control group allows determination of baseline activity of MexAB-OprM by fluorescence since MexAB-OprM can use this fluorescent dye as a substrate [26]. Cells are then resuspended in fresh media without CCCP to reverse the temporary inhibition [24,27] and the change in fluorescence is measured as the pumps are expelling EtBr out of the cells. Inhibition is shown if the rate of efflux is lowered.

Resensitizing Cells to Ampicillin using Liposomal EPI

As the MIC assays would show that the $P$. aeruginosa cells expressing MexAB-OprM were resistant to antibiotics, cells would be plated with ampicillin at a concentration below the MIC [28]. Liposomal PAßN at a concentration determined by the EtBr efflux assay to inhibit the pumps would also be added. There will be two controls: a blank control with media alone and a negative control with cells in media. Cells would be incubated at $37^{\circ} \mathrm{C}$ for 24 hours before OD is measured at $600 \mathrm{~nm}$. Results would show if the liposomal PA $\beta N$ made the bacteria susceptible to the coadminstered antibiotics again.

\section{Results}

The expected results are that MexAB-OprM overexpressing $P$. aeruginosa strains will be expected to have a higher MIC than the wildtype strain (Figure 3) whereas knockouts will be expected to be more susceptible to ampicillin, and encapsulating the EPIs in liposomes would reduce cytotoxicity to the human pulmonary epithelial cell line. In addition, liposomal EPI would maintain inhibitory activity and resistant bacteria would become susceptible to antibiotics once again when treated with the liposomal EPI. 
UNDERGRADUATE RESEARCH IN NATURAL AND CLINICAL SCIENCE AND TECHNOLOGY (URNCST) JOURNAL Read more URNCST Journal articles and submit your own today at: https://www.urncst.com

\section{Discussion}

Interpreting the expected results of the MIC assay, higher optical density would represent increased bacterial growth and resistance to ampicillin, whereas lower optical density would represent inhibited growth and susceptibility to ampicillin. When determining the liposomal EPI's cytotoxicity, fluorescence will indicate if the delivery system reduces cytotoxicity to human cells, as fluorescence will be observed within the results. Next, to measure the liposomal EPI's activity, the rate of efflux will be analyzed to observe if it is lowered compared to a control and has similar activity to free EPI. Lastly, the results of the resensitization assay would be interpreted to show that the bacteria are susceptible to antibiotics again. This would be done if the bacteria are shown to die when in combination with the liposomal EPI and the sublethal dose of antibiotics, based on the OD600.

Since this study is strictly an in vitro study, many limitations involve in vivo considerations. For example, there may be challenges regarding pharmacokinetic parameters, such as absorption and distribution of the EPIliposomal complex. Future experiments will work to study the interaction of this complex with all cellular components, including pharmacokinetic and pharmacodynamic parameters. Specifically, future experiments can be done in intestinal cell lines to further understand this approach of combating $P$. aeruginosa infections. Moreover, testing the combination of liposomal EPI and penicillin in porcine animal models, a useful model for cystic fibrosis, will better inform the clinical applications of this approach [29].

\section{Conclusions}

Overall, we expect to see MexAB-OprM pumps conferring improved resistance to $P$. aeruginosa, liposomal EPIs reducing cytotoxicity, maintenance of liposomal EPI inhibitory activity, and finally, seeing resistant bacteria become susceptible to antibiotics once again. If EPI encapsulation into liposomes reduces cytotoxicity to human pulmonary epithelial cells, further testing may be done using different antimicrobial, EPI, and cell-line combinations to determine which EPIs could have their effectiveness revived. In addition, animal models may be later used to test the safety and efficacy of this strategy. If successful, EPIs may become a potential therapeutic to combat AMR in infections by reviving the use of antimicrobials that have become ineffective. Restoring the activity of already approved antibiotics through potential co-administration with liposome-encapsulated EPIs may be a cost-effective and worthwhile approach to combat AMR.

\section{List of Abbreviations Used}

AMR: antimicrobial resistance

CCCP: carbonyl cyanide m-chlorophenylhydrazone

DPPC: dipalmitoylphosphatidylcholine

EPIs: efflux pump inhibitors

EtBr: ethidium bromide

KO: knockout

MIC: minimum inhibitory concentration

OD: optical density

OD600: optical density measured at 600nm

PA $\beta$ N: phenylalanine-arginine $\beta$-naphthylamide

P. Aeruginosa: Pseudomonas aeruginosa

\section{Conflicts of Interest}

The author(s) declare that they have no conflict of interests.

\section{Ethics Approval and/or Participant Consent}

This study did not require ethics approval.

\section{Authors' Contributions}

PR: made contributions to the design of the study, drafted the manuscript, and gave final approval of the version to be published.

$\mathrm{KN}$ : made contributions to the design of the study, drafted the manuscript, and gave final approval of the version to be published.

TN: made contributions to the design of the study, drafted the manuscript, and gave final approval of the version to be published.

SS: made contributions to the design of the study, drafted the manuscript, and gave final approval of the version to be published.

\section{Acknowledgements}

No acknowledgements.

\section{Funding}

This study was not funded.

\section{References}

[1] World Health Organization. WHO publishes list of bacteria for which new antibiotics are urgently needed. 2017 Feb 27. Available from: https://www.who.int/ news/item/27-02-2017-who-publishes-list-of-bacteriafor-which-new-antibiotics-are-urgently-needed

[2] World Health Organization. Antimicrobial resistance [Internet]. 2020 Oct. Available from: https://www.who int/news-room/fact-sheets/detail/antimicrobialresistance

[3] Howard A, O’Donoghue M, Feeney A, Sleator RD. Acinetobacter baumannii: An emerging opportunistic pathogen. Virulence. 2012;3(3):5. https://doi.org/ $\underline{10.4161 / \text { viru. } 19700}$ 
UNDERGRADUATE RESEARCH IN NATURAL AND CLINICAL SCIENCE AND TECHNOLOGY (URNCST) JOURNAL Read more URNCST Journal articles and submit your own today at: https://www.urncst.com

[4] Worlitzsch D, Tarran R, Ulrich M, Schwab U, Cekici $\mathrm{A}$, Meyer KC, et al. Effects of reduced mucus oxygen concentration in airway Pseudomonas infections of cystic fibrosis patients. Journal of Clinical Investigation. 2002 Feb 1;109(3):317-25. https://doi.org/10.1172/ JCI13870

[5] Poole K. Efflux-mediated multiresistance in gramnegative bacteria. Clinical Microbiology and Infection. 2004 Jan;10(1). https://doi.org/10.1111/j.1469-0691 2004.00763.x

[6] Lamut A, Peterlin Mašič L, Kikelj D, Tomašič T. Efflux pump inhibitors of clinically relevant multidrug resistant bacteria. Medicinal Research Reviews.

2019;39(6):2460-504.

https://doi.org/10.1002/med.21591

[7] Pu Y, Zhao Z, Li Y, Zou J, Ma Q, Zhao Y, et al. Enhanced efflux activity facilitates drug tolerance in dormant bacterial cells. Molecular Cell. $2016 \mathrm{Apr}$ 21;62(2):284-94. https://doi.org/10.1016/j.molcel.2016 .03 .035

[8] Rampioni G, Pillai CR, Longo F, Bondì R, Baldelli V, Messina M, et al. Effect of efflux pump inhibition on Pseudomonas aeruginosa transcriptome and virulence. Scientific Reports. 2017 Dec 12;7(1). https://doi.org/ 10.1038/s41598-017-11892-9

[9] Yamaguchi A, Nakashima R, Sakurai K. Structural basis of RND-type multidrug exporters. Frontiers in Microbiology. 2015 Apr 20;6. https://doi.org/10.3389/ fmicb.2015.00327

[10] Sjuts H, Vargiu A v, Kwasny SM, Nguyen ST, Kim HS, Ding X, et al. Molecular basis for inhibition of AcrB multidrug efflux pump by novel and powerful pyranopyridine derivatives. Source. 2016;113(13):3509-14. https://doi.org/10.1073/pnas.1602472113

[11] Lamers RP, Cavallari JF, Burrows LL. The efflux inhibitor phenylalanine-arginine beta-naphthylamide $(\mathrm{Pa} \beta \mathrm{N})$ permeabilizes the outer membrane of gramnegative bacteria. PloS ONE. 2013 Mar 27;8(3). https://doi.org/10.1371/journal.pone.0060666

[12] Renau TE, Léger R, Filonova L, Flamme EM, Wang $\mathrm{M}$, Yen R, et al. Conformationally-restricted analogues of efflux pump inhibitors that potentiate the activity of levofloxacin in Pseudomonas aeruginosa. Bioorganic and Medicinal Chemistry Letters. 2003 Aug 18;13(16):2755-8. https://doi.org/10.1016/s0960-894x (03)00556-0

[13] Vibe CB, Fenaroli F, Pires D, Wilson SR, Bogoeva V, Kalluru R, et al. Thioridazine in PLGA nanoparticles reduces toxicity and improves rifampicin therapy against mycobacterial infection in zebrafish. Nanotoxicology. 2016 Jul 2;10(6):680-8. https://doi.org/10.3109/17435390.2015.1107146
[14] Cannalire R, Machado D, Felicetti T, Santos Costa S, Massari S, Manfroni G, et al. Natural isoflavone biochanin $\mathrm{A}$ as a template for the design of new and potent 3-phenylquinolone efflux inhibitors against Mycobacterium avium. European Journal of Medicinal Chemistry. 2017;140:321-30. https://doi.org/10.1016/ j.ejmech.2017.09.014

[15] Wang DY, van der Mei HC, Ren Y, Busscher HJ, Shi L. Lipid-based antimicrobial delivery-systems for the treatment of bacterial infections. Frontiers in Chemistry. 2020 Jan 10;7:872. https://doi.org/10.3389/ fchem.2019.00872

[16] Cresta S, Grasselli G, Mansutti M, Martoni A, Lelli G, Capri G, et al. A randomized phase II study of combination, alternating and sequential regimens of doxorubicin and docetaxel as first-line chemotherapy for women with metastatic breast cancer. Annals of Oncology. 2004 Mar;15(3):433-9. https://doi.org /10.1093/annonc/mdh107

[17] Harbeck N, Saupe S, Jäger E, Schmidt M, Kreienberg R, Müller L, et al. A randomized phase III study evaluating pegylated liposomal doxorubicin versus capecitabine as first-line therapy for metastatic breast cancer: Results of the PELICAN study. Breast Cancer Research and Treatment. 2017 Jan 1;161(1):63-72. https://doi.org/10.1007/s10549-016-4033-3

[18] Nasser N, Hathout RM, Abd-Allah H, Sammour OA. Enhancement of oral bioavailability of drugs using lipid-based carriers: A meta-analysis study. Drug Development and Industrial Pharmacy [Internet]. 2020 Nov $13 ; 1-17$. https://doi.org/10.1080/03639045.2020.1851245

[19] Gabay M, Weizman A, Zeineh N, Kahana M, Obeid F, Allon N, et al. Liposomal carrier conjugated to APPderived peptide for brain cancer treatment. Cellular and Molecular Neurobiology. 2020;41(5):1019-1029. https://doi.org/10.1007/s10571-020-00969-1

[20] Alhariri M, Majrashi MA, Bahkali AH, Almajed FS, Azghani AO, Khiyami MA, et al. Efficacy of neutral and negatively charged liposome-loaded gentamicin on planktonic bacteria and biofilm communities. International Journal of Nanomedicine. $2017 \mathrm{Sep}$ 18;12:6949-61. https://doi.org/10.2147/IJN.S141709

[21] Alhajlan M, Alhariri M, Omri A. Efficacy and safety of liposomal clarithromycin and its effect on Pseudomonas aeruginosa virulence factors. Antimicrobial Agents and Chemotherapy. 2013 Jun;57(6):2694-704. https://doi.org/10.1128/AAC.00235-13

[22] Pesingi PV, Singh BR, Pesingi PK, Bhardwaj M, Singh SV, Kumawat M, et al. MexAB-OprM efflux pump of Pseudomonas aeruginosa offers resistance to carvacrol: A herbal antimicrobial agent. Frontiers in Microbiology. 2019 Nov 19;10. https://doi.org/ $\underline{10.3389 / \text { fmicb.2019.02664 }}$ 
UNDERGRADUATE RESEARCH IN NATURAL AND CLINICAL SCIENCE AND TECHNOLOGY (URNCST) JOURNAL

Read more URNCST Journal articles and submit your own today at: https://www.urncst.com

[23] Phair JP, Watanakunakorn C, Bannister T. In vitro susceptibility of Pseudomonas aeruginosa to carbenicillin and the combination of carbenicillin and gentamicin [Internet]. Microbiology. 1969;18. Available from: http://aem.asm.org/

[24] Mitchell CJ, Stone TA, Deber CM. Peptide-based efflux pump inhibitors of the small multidrug resistance protein from Pseudomonas aeruginosa. Antimicrobial Agents and Chemotherapy. 2019 Aug 23;63(9):e00730-19. https://doi.org/10.1128/AAC $.00730-19$

[25] Blair JMA, Piddock LJV. How to measure export via bacterial multidrug resistance efflux pumps. mBio. 2016 Jul 1;7(4). https://doi.org/10.1128/mBio.00840-16

[26] Verchère A, Dezi M, Adrien V, Broutin I, Picard M. In vitro transport activity of the fully assembled MexABOprM efflux pump from Pseudomonas aeruginosa.

Nature Communications. 2015 Apr 22;6.

https://doi.org/10.1038/ncomms7890
[27] Marshall RL, Lloyd GS, Lawler AJ, Element SJ, Kaur J, Ciusa ML, Ricci V, Tschumi A, Kühne H, Alderwick LJ, and Piddock LJV. New multidrug efflux inhibitors for gram-negative bacteria. mBio. $2020 \mathrm{Jul}$ 14;11(4). https://doi.org/10.1128/mBio.01340-20

[28] Ferrer-Espada R, Shahrour H, Pitts B, Stewart PS, Sánchez-Gómez S, Martínez-de-Tejada G. A permeability-increasing drug synergizes with bacterial efflux pump inhibitors and restores susceptibility to antibiotics in multi-drug resistant Pseudomonas aeruginosa strains. Scientific Reports. 2019 Dec 1;9(1). https://doi.org/10.1038/s41598-019-39659-4

[29] Semaniakou, A., Croll, R. P., \& Chappe, V. Animal models in the pathophysiology of cystic fibrosis. Frontiers in Pharmacology. 2018 Jan 4;9. https://doi.org/10.3389/fphar.2018.01475

\section{Article Information}

Managing Editor: Jeremy Y. Ng

Peer Reviewers: Vanessa Susevski, Foram Vyas

Article Dates: Received Apr 27 21; Accepted Aug 10 21; Published Sep 1521

\section{Citation}

Please cite this article as follows:

Ray P, Nguyen K, Nguyen T, Sachdev S. Resurrecting the dead: Mitigating efflux-pump inhibitor toxicity using a liposomal delivery system to recover efficacy of antimicrobial drugs. URNCST Journal. 2021 Sep 15:5(9).

https://urncst.com/index.php/urncst/article/view/278

DOI Link: https://doi.org/10.26685/urncst.278

\section{Copyright}

(C) Prachi Ray, Kha Nguyen, Truong Nguyen, Sukriti Sachdev. (2021). Published first in the Undergraduate Research in Natural and Clinical Science and Technology (URNCST) Journal. This is an open access article distributed under the terms of the Creative Commons Attribution License (https://creativecommons.org/licenses/by/4.0/), which permits unrestricted use, distribution, and reproduction in any medium, provided the original work, first published in the Undergraduate Research in Natural and Clinical Science and Technology (URNCST) Journal, is properly cited. The complete bibliographic information, a link to the original publication on http://www.urncst.com, as well as this copyright and license information must be included.
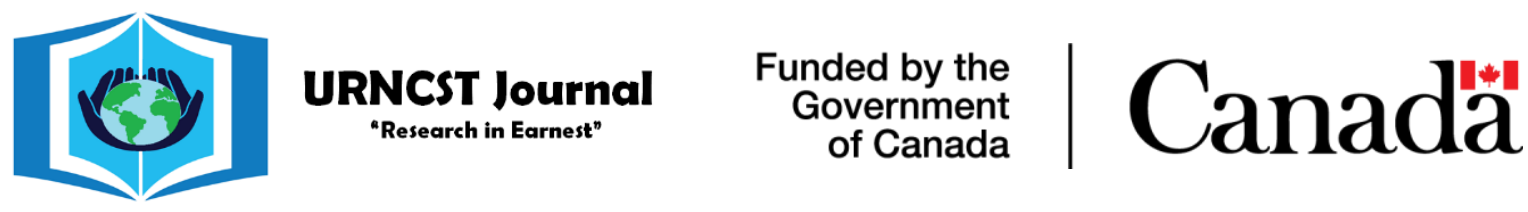

Do you research in earnest? Submit your next undergraduate research article to the URNCST Journal!

| Open Access | Peer-Reviewed | Rapid Turnaround Time | International |

| Broad and Multidisciplinary | Indexed | Innovative | Social Media Promoted |

Pre-submission inquiries? Send us an email at info@ urncst.com | Facebook, Twitter and LinkedIn: @URNCST

Submit YOUR manuscript today at https://www.urncst.com!

Ray et al. | URNCST Journal (2021): Volume 5, Issue 9

Page 7 of 7

DOI Link: https://doi.org/10.26685/urncst.278 